Maria Małanicz-Przybylska

ORCID: https://orcid.org/0000-0001-9841-3871

Uniwersytet Warszawski

Instytut Etnologii i Antropologii Kulturowej

\title{
Intensywna praca dziedzictwa - działania liderów w miasteczku Wilamowice
}

\section{Intensive work of heritage - local leaders' activities in the small town of Wilamowice}

\begin{abstract}
Wilamowice, a small town located in Bielsko County, has an extremely interesting history and an ambiguous heritage. Its inhabitants, descendants of medieval Germanic settlers, for many centuries used their own language, which was incomprehensible to their neighbours, namely the Vilamovian language. They also preserved their own customs and costumes. After the $2^{\text {nd }}$ World War, the process of forgetting the Vilamovian heritage began. It was only in the $21^{\text {st }}$ century that young activists from Wilamowice started to work on the revitalization of local culture. Their goal was to document and reconstruct selected elements of local heritage. By involving the inhabitants of Wilamowice in various activities which they undertook, they influenced the way people perceived their own heritage and affected the process of constructing modern Vilamovian identity. In this article I analyse these ongoing processes of "intensive work of heritage".
\end{abstract}

Key words: Wilamowice, heritage, tradition

Położone w powiecie bielskim miasteczko Wilamowice ma ciekawą historię i niejednoznaczne dziedzictwo. Jego mieszkańcy, potomkowie średniowiecznych osadników, przez długie stulecia posługiwali się swoim własnym, niezrozumiałym dla sąsiadów językiem wilamowskim, posiadali własne zwyczaje i stroje. Po II wojnie światowej rozpoczął się proces zapominania wilamowskiego dziedzictwa. Dopiero w XXI wieku młodzi aktywiści z Wilamowic zaczęli walczyć o rewitalizację rodzimej kultury. Ich celem stało się dokumentowanie i rekonstruowanie wybranych elementów lokalnego dziedzictwa. Wciągając mieszkańców Wilamowic w różne podejmowane przez siebie działania, zaczęli aktywnie wpływać na sposób 
postrzegania własnego dziedzictwa i nowoczesne konstruowanie wilamowskiej tożsamości. Właśnie o tych aktualnych procesach „intensywnej pracy dziedzictwa” traktuje niniejszy tekst.

Słowa kluczowe: Wilamowice, dziedzictwo, tradycja

Odebrano / Received: 04.02.2021

Zaakceptowano / Accepted: 05.10.2021

Dnia 24 lutego 2018 roku w Wilamowicach odbyła się premiera spektaklu zatytu-

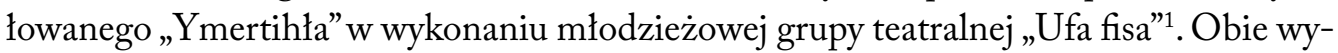
stępujące w poprzednim zdaniu nazwy składają się z wyrazów w języku wilamowskim, zaś samo przedstawienie stało się przykładem i dowodem na możliwość rewitalizacji tego ginącego etnolektu. Tytułowa „Ymertihła” to inaczej „Odziewaczka” - element wilamowskiego stroju kobiecego, chusta, którą kobiety zarzucały dawniej na ramiona (Król 2020a: 232). Właśnie ta chusta stała się nicią narracyjną spektaklu, połączyła losy bohaterów. Historia wystawiana na scenie jest bowiem podróżą w czasie, rozpoczyna się w 1938 roku, a kończy w czasach współczesnych. „Odziewaczka” to niemy świadek różnych wydarzeń, które zdają się przekonywać: kultura wilamowska, niezwykła, bogata, choć atakowana, represjonowana przez różne strony, przetrwała i nadal jest ważnym elementem tożsamości współczesnych wilamowian. Głównymi ukazanymi w przedstawieniu „zagrożeniami” dla kultury wilamowskiej okazali się Polacy i Niemcy, którzy w różnych momentach historycznych chcieli przeciągnąć wilamowian na swoją stronę, albo oskarżając ich o identyfikowanie się z wrogiem, poddawali różnego rodzaju opresjom. Tym samym wilamowskość ukazana $\mathrm{w}$ przedstawieniu staje się dziedzictwem w międzykulturowym potrzasku.

Mnie jednak zastanawia inna kwestia. Otóż sądzę, że spektakl „Ymertihła” jest świetnym przykładem intensywnej pracy dziedzictwa, którą bardzo skrupulatnie i celowo projektują, a następnie realizują przy pomocy lokalnej wspólnoty charyzmatyczni liderzy wilamowskości (por. Shils 1984). I o tym właśnie chcę w niniejszym tekście opowiedzieć - w jaki sposób różnego rodzaju działania podejmowane przez lokalnych liderów przyczyniają się do wytwarzania lokalnego, małomiasteczkowego dziedzictwa Wilamowic, a także w jaki sposób owo dziedzictwo wpływa na budowanie wilamowskiej tożsamości. Moje spostrzeżenia i wnioski wynikają z etnograficznych badań terenowych, które prowadziłam w Wilamowicach w latach 2015-2017. Badania te dotyczyły przede wszystkim muzyki Wilamowic. Rozmawiając z mieszkańcami miasteczka, uczestnicząc w ich życiu codziennym i świątecznym, starałam się zrozumieć, czym jest muzyczne dziedzictwo Wilamowic i w jaki sposób współcześni Wilamowianie wykorzystują

\footnotetext{
1 Później, 16 listopada 2018 roku, przedstawienie zostało pokazane także w Teatrze Polskim w Warszawie.
} 
muzykę do budowania lokalnej tożsamości, oraz wspólnoty. Wyniki moich badań opublikowałam w książce Bez muzyki, bez śpiewu nie ma świata. Muzyka w Wilamowicach (Małanicz-Przybylska 2019). Oczywiście nie wszystkie materiały z moich badań zostały ujęte $\mathrm{w}$ monografii. Podstawą zawartych w niniejszym artykule analiz staną się zatem przede wszystkim fragmenty moich rozmów w wilamowianami (zapisywane w tekście kursywą), a także notatki terenowe sporządzane na podstawie obserwacji uczestniczącej. Do analizy posłużą mi także różnego rodzaju wypowiedzi medialne liderów wilamowskości, uważam bowiem, że oficjalne, zewnętrze prezentowanie dziedzictwa także jest ważnym sposobem jego wytwarzania.

Dziedzictwo stało się obecnie bardzo popularnym słowem w wymiarze językowym, potocznym i politycznym. Ale jest ono także koncepcją naukową, która wciąż podlega redefiniowaniu i modelowaniu. To kategoria modna dyskursywnie, która być może w dobry sposób opisuje ducha naszych czasów - pierwszych dekad XXI wieku (Galusek, Jagodzińska 2014). Jak pisała Laurajane Smith, „[c]oraz obszerniejsza literatura, wyrastająca $z$ obserwacji, że dziedzictwo to «jeden z najważniejszych [...] ruchów społecznych naszych czasów», oraz że «dziedzictwo kulturowe nie istnieje, ono jest wytwarzane», kwestionuje tradycyjne definicje dziedzictwa" (Smith 2016: 26). Zdaniem autorki podmiotowe postrzeganie dziedzictwa, które wciąż promowane jest przez różnego rodzaju instytucje z $\mathrm{UNESCO}^{2}$ na czele, coraz mniej ma wspólnego z rzeczywistością. Dziedzictwem, pisała Smith, nie są zatem rzeczy, miejsca, ani zdarzenia (Smith 2016: 30). Dla niej najważniejsze staje się działanie, akcja, proces. Dlatego też dziedzictwem nazywa „procesy wytwarzania znaczeń, do których dochodzi, gdy miejsca lub wydarzenia są rozpoznawane jako dziedzictwo, kiedy się nimi zarządza, definiuje je, wystawia, zwiedza i ogląda" (Smith 2016: 30). Dziedzictwo oczywiście odnosi się do przeszłości, jednak jego celem jest nadawanie sensu teraźniejszości, wytwarzanie określonych tożsamości poprzez „negocjowania historycznych i kulturowych znaczeń i wartości związanych z naszymi decyzjami o tym, by zachować pewne przedmioty, miejsca czy wydarzenia" (Smith 2016: 30). W podobnym znaczeniu pisał o dziedzictwie David Lowenthal, twierdząc, że dziedzictwo polega na wypaczaniu, przeinaczaniu przeszłości tak, by pasowała do współczesnych celów i potrzeb konkretnych wspólnot. Dlatego też dziedzictwo pokazuje przeszłość zinterpretowaną, jednoznaczną (Lowenthal 1998). Derek Gillman pisal, że dziedzictwem należy nazwać te historie, które sami lubimy o sobie opowiadać, bo podkreślają nasze osiągnięcia, a umniejszają błędy (Gillman 2010). Jak postaram się pokazać na przykładzie Wilamowic, czasem dziedzictwem celowo chce się jednak uczynić także te treści, które pokazują niedolę, dramatyczne losy jakiejś grupy. Bliskie jest mi podejście Barbary Kirshenblatt-Gimblett, dla której

2 Autorka krytykuje także w tym względzie zaproponowaną przez UNESCO kategorię dziedzictwa niematerialnego, wskazując, że najczęściej w praktyce jest ono również sprowadzane do materialnej postaci (Smith 2016: 26-27). 
dziedzictwo jest „sposobem produkcji kulturowej, który sięga po przeszłość i tworzy coś nowego“" (Kirshenblatt-Gimblett 2011: 126). Dla mnie kluczowy jest wspólnotowy wymiar dziedzictwa - tworzone i przetwarzane ze wspomnień oraz doświadczeń działa jako interpersonalne relacje wiążące ludzi ze sobą i w ten sposób przyczynia się do powstawania społecznych tożsamości (Smith 2006).

Ponieważ dziedzictwo powstaje w ścisłej relacji do przeszłości, wydaje mi się, że aby zrozumieć współczesne procesy wytwarzania owego dziedzictwa w Wilamowicach, warto choć szkicowo nakreślić historię tego miejsca i jego mieszkańców. Ona okazuje się bowiem kluczem interpretacyjnym do aktualnych działań i generowanych przez nie znaczeń.

Wilamowice to liczące nieco ponad 3000 mieszkańców miasto w powiecie bielskim - położone nieopodal granicy województw śląskiego i małopolskiego. Choć współcześnie polska administracja nie posługuje się terminem „miasteczko”, ja Wilamowice tak właśnie nazywam - miasteczkiem. Oficjalnie są miastem - prawa miejskie otrzymały już ponad 200 lat temu - w 1818 roku. Dawniej słynęły z najlepszych tkaczy w okolicy, a także z najbardziej zaradnych handlarzy. Waśnie ten tkacko-kupiecki charakter Wilamowic zdecydował o wyjątkowości i zamożności miasteczka, które przekładały się również na rozwój infrastruktury i powstawanie miejskich urzędów oraz instytucji. $Z$ drugiej jednak strony jeszcze na początku XX wieku nadal wiele osób utrzymywało się tam z uprawy ziemi, posiadało gospodarstwa, hodowało zwierzęta. Poza miejskim placem centralnym i kilkoma sąsiadującymi z nim ulicami, zabudowa raczej przypominała wieś.

Dziś oczywiście wiele się zmieniło. Stare wiejskie chaty zostały zastąpione przez nowoczesne, okazałe domy i wille (choć gdzieniegdzie można jeszcze zobaczyć dawne $\mathrm{w}$ połowie murowane, a w połowie drewniane zabudowania). Odremontowany rynek stanowi centrum miasteczka, gdzie załatwić można właściwie wszystkie sprawy - tam znajdują się sklepy, bank, apteka, zakład ubezpieczeniowy i pogrzebowy, nieopodal straż pożarna, szkoła i przedszkole, świetlica dla seniorów, fryzjer, biblioteka i poczta. Ponad miasteczkiem wznosi się wysoka wieża okazałego kościoła.

Tkactwo nie jest już specjalnością wilamowian, choć działa tam jeden zakład odzieżowy produkujący kurtki i płaszcze - Biba Styl. Większość mieszkańców znajduje jednak zatrudnienie w licznych prywatnych firmach i zakładach w okolicy, m.in. usługowych, niektórzy nadal dojeżdżają do kopalń i zakładów przemysłowych w Bielsku, Brzeszczach, Oświęcimiu czy Czechowicach. Niewielkie gospodarstwa rolne zazwyczaj są tylko dodatkiem do innej pracy zarobkowej (Michalczyk 2001: 275). O małomiasteczkowości Wilamowic decyduje ich charakter. Tu naprawdę wszyscy znają wszystkich. Informacje, plotki, ciekawostki rozchodzą się bardzo szybko. W razie potrzeby można liczyć na blyskawiczną pomoc sąsiadów i znajomych, ale też trudno ukryć takie rzeczy, które wolałoby się zachować w tajemnicy.

Przed wojną Wilamowice $\mathrm{z}$ całą pewnością można było nazwać miasteczkiem wielokulturowym. Przodkowie współczesnych wilamowian przybyli na te tereny 
w średniowieczu z daleka. Skąd dokładnie, nie ma pewności. Wiadomo natomiast, że w XIII wieku założono tu wieś na prawie niemieckim (Reyniak 2001), językoznawcy uważają, że osadnicy prawdopodobnie byli pochodzenia germańskiego (Wicherkiewicz 2003). Najważniejsze wydaje mi się jednak to, że przez całe stulecia potomkowie dawnych osadników zachowali swój własny wilamowski język (brzmiący germańsko, choć niektórzy uważają, że holendersko), własne tradycje i zwyczaje. Byli więc zawsze trochę inni, trochę obcy wśród polskojęzycznej większości i, co istotniejsze, także sąsiedzi uważali ich za obcych (Libera, Robotycki 2001). Niewiele wiadomo o dawnych dziejach Wilamowic. Pewniejsze informacje pochodzą z XVII wieku - już wtedy poza rolnikami w miejscowości pracowało wielu rzemieślników - krawców, kowali, piekarzy, szewców itd., więc Wilamowice przypominały nieco miasteczko (Barciak 2001: 100). Po rozbiorach Rzeczypospolitej stały się częścią monarchii Habsburgów i prawdopodobnie od tego momentu można mówić o poczuciu lokalnej tożsamości. Liczne swobody i przywileje przyznawane przez habsburskich zwierzchników doprowadziły do sytuacji, w której społeczność wilamowian powzięła decyzję o wykupieniu się z poddaństwa. Udało im się tego dokonać w 1808 roku. Właśnie kolejne dziesięciolecia - aż do wybuchu II wojny światowej były najlepszym czasem dla miasteczka i jego mieszkańców. Rozwijano warsztaty tkackie, w których wytwarzano świetnej jakości tkaniny, zorganizowano tkacką szkołę (Michalczyk 2001). Handlarze z Wilamowic rozwozili swoje tkaniny do wielu zakątków Europy, a nawet do Konstantynopola (Michalczyk 2001: 269). Z podróży handlowych kupcy wracali nie tylko bogaci, ale przywozili także różne obserwacje dotyczące innych miejsc i kultur, niektóre z nich (jak choćby melodie) włączali później do lokalnego obiegu.

Wilamowska prosperity przerwała wydarzenia II wojny światowej, a szczególnie to, co stało się tuż po wojnie. Ponieważ większość wilamowian podpisała volkslisty, przez powojenne władze, a także okoliczną ludność uznani zostali za zdrajców, za co spotkały ich różne prześladowania. By zapobiec aktom przemocy, władze zakazały używania języka wilamowskiego i noszenia wilamowskich strojów. Okoliczności te doprowadziły do celowego „zapominania” tych elementów własnego dziedzictwa, które kojarzone były „niemiecko”. Inne zaś elementy - takie jak muzyka i tańce, strój - wkrótce zostały zaprzęgnięte $\mathrm{w}$ projekt folklorystycznego prezentowania różnorodności kulturowej Polskiej Rzeczpospolitej Ludowej. Znalazły swoich apologetów i „kreatorów”, stawały się zatem częścią polskiego dziedzictwa ludowego. Kładziono nacisk na walory estetyczne, wymazując kulturowy kontekst ich funkcjonowania. Czasy Polski Ludowej paradoksalnie przyczyniły się jednak do zachowania pewnych elementów kultury wilamowskiej, które, choć zmieniane lub wymyślanie całkiem od nowa, przetrwały $\mathrm{w}$ repertuarze Regionalnego Zespołu Pieśni i Tańca „Wilamowice” kierowanego wówczas przez charyzmatyczną Jadwigę Stanecką (Małanicz-Przybylska 2018).

Dużo trudniejsze czasy nadeszły dla kultury wilamowskiej w latach 90 . XX wieku. Państwowe dotacje na działalność zespołów regionalnych zaczęły się kurczyć, Cepelia 
nie pomagała. $Z$ drugiej strony kultury wilamowskiej nikt już nie prześladował, a tym samym poczucie konieczności walki o nią stawało się coraz słabsze. Język wilamowski znali już tylko najstarsi wilamowianie, naukowcy wieszczyli jego rychłą śmierć (Wicherkiewicz 2003). Z braku funduszy i personalnych nieporozumień przestał działać zespół regionalny. Tylko dzieci tańczyły jeszcze w zespole „Fil”.

Ten właśnie czas mógł stać się końcem odrębności kulturowej miasteczka. Ale właśnie wtedy - na początku lat 90. XX wieku urodzili się ludzie, którzy kilkanaście lat później postawili sobie za cel odbudowę, czy też jak sami mówią, rewitalizację wilamowskiej kultury - przede wszystkim języka, strojów, ale też pamięci o wilamowskiej historii. Ich celem stało się dokumentowanie i rekonstruowanie wybranych elementów lokalnego dziedzictwa. Jednocześnie, co mi wydaje się najbardziej interesujące, wciągając mieszkańców Wilamowic w różne podejmowane przez siebie działania, zaczęli aktywnie wpływać na sposób postrzegania lokalnego dziedzictwa i nowoczesne konstruowanie wilamowskiej tożsamości.

\section{Dziedzictwo (re)konstruowane}

Głównymi treściami, wokół których koncentruje się współczesna praca dziedzictwa w Wilamowicach, są wilamowski język, następnie wilamowskie stroje, w końcu zwyczaje i muzyka. Wszystkie one uwikłane są w narracje dotyczące postrzegania i rozumienia historii miasteczka. Kiedy po II wojnie światowej zakazano mówienia po wilamowsku, transmisja międzypokoleniowa została przerwana. Młodzi nie znali wilamowskiego, starsi w miejscach publicznych bali się nim porozumiewać, język ten w końcu stał się więc przede wszystkim kodem komunikacji najstarszego pokolenia. I właśnie ta dziwna mowa wilamowskich babć na początku XX wieku zainteresowała gimnazjalistę Tymoteusza Króla. Kilkunastoletni Tymek dostał dyktafon i zaczął nagrywać różne „babcie”, przede wszystkim swoją dziecięcą opiekunkę. Ta pasja nagrywania, później także rozmów po polsku dotyczących historii i tradycji Wilamowic, stała się jego życiowym projektem. Tymoteusz Król zgromadził tysiące godzin materiałów. Z nagrań uczył się wilamowskiego, a później postanowił ten język wskrzesić, organizując darmowe lekcje wilamowskiego dla dzieci i młodzieży³. W 2007 roku z jego inicjatywy Biblioteka Kongresu Stanów Zjednoczonych wpisała język wilamowski do rejestrów języków świata (Sepioło 2018).

Warto nadmienić, że wilamowskiego wcześniej niż Tymek nauczał w miasteczku lokalny poeta Józef Gara, na którego lekcje uczęszczała druga ze współczesnych liderek wilamowskości, Justyna Majerska-Sznajder. Justyna i Tymek byli kolegami ze szkoły.

\footnotetext{
3 Wszystkie powyższe informacje pochodzą z moich rozmów z Tymoteuszem Królem, który był moim głównym przewodnikiem po Wilamowicach zarówno w sensie przestrzennym, jak i społecznym. Tymoteusza Króla uważam także za swojego serdecznego znajomego, dlatego niekiedy posługuję się wyłącznie jego imieniem.
} 
Najpierw połączyło ich zainteresowanie językiem wilamowskim, a później wszystkim, co wilamowskie. Jeszcze jako nastolatkowie zaczęli penetrować strychy i garaże sąsiadów, zbierając różne stare ubrania, ale też inne przedmioty należące do kultury materialnej. Później oboje zaangażowali się w działania Stowarzyszenia na Rzecz Zachowania Dziedzictwa Kulturowego Miasta Wilamowice „Wilamowianie” oraz Regionalnego Zespołu Pieśni i Tańca „Wilamowice”, przyczyniając się do jego reaktywacji.

Choć na studia wyjechali z Wilamowic, po ich zakończeniu wrócili i dziś aktywnie działają na rzecz dziedzictwa miasteczka. Pracują naukowo - oboje prowadzą badania i piszą doktoraty związane $z$ Wilamowicami. Są także popularyzatorami wiedzy o Wilamowicach w mediach, podczas różnych imprez folklorystycznych, ale też w środowisku akademickim. Publikują teksty popularne i naukowe, zapraszają do współpracy innych badaczy. Ponadto intensywnie pracują lokalnie - nadal działają w miejscowych instytucjach, angażują się w prace i inicjatywy wilamowian, Justyna Majerska-Sznajder jest prezeską wspomnianego stowarzyszenia.

Kiedy zaczynałam badania w Wilamowicach, niemal każda rozmowa rozpoczynała się od próby wysłania mnie do Tymka lub Justyny. Gdy mówiłam, że to oni mnie tu właśnie przysłali, widziałam w oczach moich rozmówców pewien zawód, jakby czuli, że tylko ta dwójka naprawdę coś o Wilamowicach wie. Wielu wilamowian postrzega tych młodych aktywistów jako powierników swojej „spuścizny”, ma do nich zaufanie i przekazuje im swoje największe skarby. Słyszałam na ten temat wiele historii. Na przykład były kapelmistrz orkiestry dętej spisał i opracował melodie weselne, które opatrzył następującym wstępem:

Tymoteusz Król. $Z$ wielką radością pragnę wspierać Twoją wolę ocalenia wszystkiego, co związane było z kulturą i obyczajami naszych przodków w Wilamowicach. W tym przewodniku piszę melodie grane przez orkiestrę i śpiewane przez weselników... ${ }^{4}$.

Inni wilamowianie także dostrzegają i doceniają pracę liderów. Mówił mi o tym znany perkusista jazzowy, pochodzący z miasteczka:

Bo jak chodzi o Wilamowice, to on [Tymek - przyp. aut.] zawsze. Jak tylko hasło Wilamowice, to on tu zawsze jest gotowy, od razu. To się nazywa pozytywnie nakręcony. On jest z tych. On uczy tutaj, ten język, gdzieś programy, ma układy, przyjeżdżają telewizje.

Dla osób tańczących i śpiewających w zespole „Wilamowice” Tymek i Justyna stają się też wyroczniami, jeśli chodzi o poprawność kompletowania strojów na różne okazje oraz odpowiedniego wypowiadania słów wilamowskich piosenek.

\footnotetext{
${ }^{4}$ Napisany do Tymoteusza Króla list na głos odczytał mi jego autor. Wszystkie cytaty zapisane w niniejszej pracy kursywą są fragmentami wypowiedzi moich rozmówców.
} 
Działalność tej dwójki na rzecz wilamowskiej wspólnoty bez wątpienia trudno przecenić. Sądzę jednak, że ta aktywność na wielu różnych polach przyczynia się nie tylko do zachowania dziedzictwa Wilamowic, ale także do jego wytwarzania. Jeśli, jak pisał David Lowenthal, dziedzictwo jest procesem zawłaszczania historii i nadawania jej wymiaru emocjonalnego (Lowenthal 1998), to moim zdaniem właśnie tak można określić część działań wilamowskich aktywistów. Najwyraźniejszym nurtem tego procesu jest wybieranie oraz uwypuklanie konkretnych wątków historycznych, które wyposażane są w określone znaczenia i sposoby wartościowania. W założeniu powinny następnie zostać zaakceptowane i zinternalizowane przez całą społeczność.

$\mathrm{Z}$ moich badań i obserwacji wynika, że w przypadku wilamowskich ruchów rewitalizujących tym wybranym na dziedzictwo momentem historycznym stają się powojenne prześladowania. Lokalni liderzy promują konkretną narrację historyczną dotyczącą tych wydarzeń i na niej opierają wiele swoich działań. W jednym z wywiadów prasowych Tymoteusz Król mówił być. „Mamy też inną historię. Nasza pamięć m.in. za sprawą powojennych prześladowań, jest inna, niż pamięć polska. Inaczej zapamiętaliśmy różne wydarzenia z przeszłości, jak choćby żołnierzy wyklętych i ich działalność czy volkslisty. Nasza pamięć lokalna jest inna" (Furtak 2020). W swoim tekście naukowym Tymoteusz Król pisał, że można współcześnie zostać publicznie upomnianym za używanie języka wilamowskiego na przykład $\mathrm{w}$ autobusie, a sytuacje takie interpretowane są przez ludzi jako podobne do tych z 1945 roku (Król 2016: 253). Przywoływanie i podkreślanie wagi prześladowań, które sprowokowane były innością wilamowian, można rozumieć jako próbę konstruowania konkretnej wizji historii. Na jej podstawie powstaje narracja tożsamościowa, która w dalszym ciągu ukazuje wilamowian jako obcych i poprzez tę obcość postrzeganych negatywnie. Justyna Majerska w jednym $z$ wywiadów prasowych powiedziała tak: „Kiedy uczyliśmy wilamowskiego po domach, zdarzały się telefony ze skarga$\mathrm{mi}, \dot{z ̇ e}$ robimy to bezprawnie [...]. Pokutowało myślenie, że wilamowski powinien być już dawno zapomniany, bo wiązał się z pamięcią o powojennych prześladowaniach. I panowało przeświadczenie, że wokół Wilamowic ciągle żyją ci, którzy po wojnie krzywdzili Wilamowian”. Dalej w tym samym wywiadzie dodała: „W szkole Tymek słyszał od dzieciaków z innej miejscowości: Ty folksdojczu!"(Sepioło 2018).

Ostatnia wypowiedź,jak sądzę, odnosi się do dwóch przestrzeni - językowej (wilamowianie nie mówili po polsku) i historycznej (podpisali volkslisty - nie są więc Polakami). Sytuacja wyzywania chłopca takimi słowami w XXI wieku wydaje mi się niezwykle ciekawa. Jego koledzy nie mogli przecież pamiętać wydarzeń II wojny światowej, choć naturalnie mogli o nich słyszeć od pradziadków lub dziadków. Warto jednak zauważyć, że na początku tego stulecia prawie nikt nie mówił już po wilamowsku (Król 2016), więc świadomość dzieci z okolicy, że w Wilamowicach używa się innego języka, jeżeli była, to też raczej pochodziła z przestrzeni wyobrażeń potocznych (Geertz 2000). Zbigniew Libera i Czesław Robotycki, którzy robili badania na temat wyobrażeń o wilamowianach wśród mieszkańców gminy, pisali, że obcość także współcześnie jest 
elementem postrzegania mieszkańców Wilamowic (Libera, Robotycki 2001). Badacze twierdzili jednak, że aktualnie największy wpływ na potoczny wizerunek wilamowian mają „„́wiaty zewnętrzne” (Libera, Robotycki 2001: 372), na które składały się przekazy medialne, działania lokalnych polityków zmierzające do promowania gminy, a także badania naukowe ${ }^{5}$, „[D]o Wilamowic i okolic zjeżdżały przez kilka lat liczne grupy studentów i ich uczonych opiekunów, co musiało wpływać na poglądy mieszkańców gminy indagowanych wielokrotnie na różne tematy" (Libera, Robotycki 2001: 373). Z ich badań wynika, że odmienny język faktycznie był jednym z elementów definiowania owej inności. Nie odnotowali jednak łączenia go z kwestiami politycznymi i dramatycznymi wydarzeniami II wojny światowej. Ludzie raczej opisywali ów język jako egzotyczny, niezrozumiały, tajemniczy, służący do obgadywania, co miało obrazować przezwisko „chołdy-bołdy”. Jego pochodzenie nie stanowiło ważnej ani nawet jasno określonej kwestii: „szwargocą tam jakimś serbsko-chorwackim, dolno-niemiecko-łużyckim” - powiedziała im jedna z rozmówczyń (Libera, Robotycki 2001: 385).

Znacznie więcej niż język negatywnych emocji wzbudzały takie cechy potocznie przypisywane wilamowianom, jak przekonanie o zamkniętym charakterze tej społeczności i wrogie nastawienie do ludzi z zewnątrz. Rozmówcy Robotyckiego i Libery mówili jednak również o wilamowskiej pracowitości i wynikającej z niej zamożności, o kulturze osobistej, dbaniu o porządek. A zatem ten obraz nie był jednoznacznie negatywny. Mnie udało się usłyszeć podobne wypowiedzi. Jedna z moich rozmówczyń mówiła:

Tata mi opowiadał, że dawniej, to tu nie mógł nikt przyjść obcy. Tylko między sobą. Wilamowian z wilamowianką. Nie dopuszczali, żeby przyszła obca dziewczyna. Chłopak to nawet podobno dostał od wilamowianów, jak tu przychodził, tak mi tata opowiadał, że jak przyszedł do jakiejś wilamowianki, to mu wpieprzyli.

Wszystkie jej słowa dotyczyły jednak przeszłości. Inny mężczyzna mówił natomiast, że wilamowianie uważają się za lepszych i oceniają innych pod względem majętności: Lepszy, bo jest stąd i lepszy, bo ma tu kasę. Też na to patrzq ci rodowici wilamowianie. Wiele osób mówiło mi jednak, że dziś nie ma już większego znaczenia, czy pochodzi się z Wilamowic, czy z okolicy, że zanikają różnice między mieszkańcami gminy, coraz więcej jest też małżeństw wilamowian $\mathrm{z}$ nie-wilamowianami, nawet $\mathrm{w}$ zespole regionalnym tańczą nie-wilamowianie i nikomu to nie przeszkadza.

Czy zatem do dziś wilamowianie są prześladowani, jak w czasach powojennych, za swoją niepolską tożsamość? Czy pozostała w nich trauma, która wymaga przepracowania? Nie wiem, mnie nie udało się odnaleźć takich treści podczas badań w Wilamowicach. Ponadto dla większości moich rozmówców tożsamości polska i wilamowska wcale nie

\footnotetext{
5 Podobny proces popularyzacji treści wilamowskich dostrzegł także Tymoteusz Król (Król 2016).
} 
były rozłączne, ani tym bardziej przeciwstawne. Czuli się Polakami i jednocześnie szczycili się swoją lokalnością, wyjątkową kulturą małej ojczyzny. Zdecydowanie podczas rozmów, jakie prowadziłam $\mathrm{z}$ wilamowianami, ich historia i dziedzictwo objawiały się jako powód do dumy, a nie przyczyna traumy.

Zresztą powody, dla których mieszkańcy Wilamowic (nie tylko rodowici wilamowianie, co warto podkreślić) angażują się w różne działania na rzecz rewitalizacji dziedzictwa, są bardzo różne. Liderom wilamowskości udało się zaszczepić zarówno w młodych, jak i w starszych mieszkańcach przekonanie, że „wilamowskośc”” może być atrakcyjna nie tylko jako folklorystyczna ciekawostka do prezentowania na zewnątrz, ale także jako sposób lokalnego działania. Taką oazą codziennego celebrowania wilamowskości są m.in. próby zespołu „Wilamowice”. Oczywiście przyszłe występy stają się motywacją do pracy, jednak mam wrażenie, że nie one są tu najważniejsze. Zespół jest jedną z niewielu (a może wręcz jedyną) propozycją zagospodarowania wolnego czasu, która jednocześnie wytwarza poczucie wspólnoty zakorzenionej w lokalności, łączy ludzi w różnym wieku (od 8 do ponad 90 lat), jest formą fizycznej rekreacji i daje okazję do wyjazdów. Podczas prób członkowie ćwiczą poszczególne układy, ale przede wszystkim są razem, rozmawiają o ważnych dla miasteczka sprawach, plotkują, świętują swoje urodziny itd. Muzyka i taniec stają się zatem pretekstem do bycia razem. Jeden licealista, członek zespołu uczący się w Brzeszczach, tak o tym mówił:

Ogólnie wesoło jest w zespole, naprawdę. Jak byście były na jakimkolwiek wyjeździe za granicą, to jest „tak” (pokazuje ręką gest, że jest git - przyp. aut.).W sumie to też przyciagga ludzi tych nowych, jak się im opowiada. W szkole, jak im opowiadam, jak fajnie było na jakimś wyjeździe, to często: o kurcze, szkoda, że nie jestem z Wilamowic, bo bym chodził.

Inna osoba podkreślała wspólnotowy wymiar zespołu:

w ogóle jesteśmy jak taka rodzina. Zdarzają się sprzeczki, ale ogólnie to wszyscy wszystkich szanują... No bo my tam jesteśmy zżyci z sobą dosyć, taka prawda.

Jednocześnie, $z$ inicjatywy liderów wilamowskości wśród członków zespołu pewne treści dotyczące dziedzictwa stają się nie tylko obecne, ale i ogromnie ważne. Oczywiście $\mathrm{z}$ ust wielu moich rozmówców w każdym wieku padały deklaracje podobne do tej: No gtównie siedzę w zespole dla tych wystepów, dla pokazywania tej naszej kultury i tak dalej. W trakcie moich badań zauważyłam także, że szczególnie członkinie zespołu ogromną wagę przywiązują do wilamowskich strojów - rozmawiają o nich, radzą się wzajemnie w kwestiach kompletowania, czasami nawet kłócą lub krytykują za nieodpowiednie ubranie. Wiele z pań dopiero po dołączeniu do zespołu zaczęło w ogóle zabiegać o posiadanie elementów wilamowskiego ubioru. 
Ja jeszcze pracowałam, miałam podopieczną taką panią ... i ona tam miała odziewaczkę. To się pytałam, czy mogę wziąć, no to mi dała tą odziewaczkę. A zaraz naprzeciwko to taka pani też miała taką spódnice pasiastą i mówi: jak chcesz, to se to weź. No a mówi, jak nie chcesz, to daj Tymkowi... Przymierzyłam, mówię, dobra jest na mnie, no to se wzięłam. Tylko oplecek to był taki malutki... No to oplecek mi zaś Danusia uszyła. Czepki też mi Danusia poszyła, co jej resztki zostały z tych oplecków... To tyle tylko mam. A bluzkę to też dostałam za coś, też właśnie od tej Foksowej... Wzięłam trzy takie chustki i poszłam do tej Foksowej. I mówię: pani Foksowo, uszyjecie mi oplecek, ja tu przyniosłam trzy chustki. Ona tak ogląda: a wiesz co, ja bym se te chustki wzięła. A to se weźcie, mówię, ale oplecek najwyżej będę mieć zespołowy. Ale że nie chciałam żadnych pieniędzy, to wzięłam mi uszyła tą białą jypłę. To ja ci uszyję jypłę, będziesz mieć swoją. No dobra.

Zespołowa młodzież także zwraca uwagę na strój. Niektórzy używają jego elementów poza sceną - w życiu codziennym jako oryginalny dodatek do współczesnych ubrań (Król 2020b). Fotografie w strojach wykorzystywane są jako zdjęcia profilowe na Facebooku zarówno przez młodzież jak i starszych Wilamowian. Sądzę, że kwestie oryginalności i poczucia wyjątkowości stają się też motywacją młodzieży do nauki języka wilamowskiego. Przekonywał mnie o tym jeden z moich rozmówców:

To jest plus - można rozmawiać ze znajomymi. Na przykład stoję z kolegą i mamy ochotę poobgadywać znajomych, co stoją obok, no to możemy po wilamowsku. No wiadomo, jak to jest - nie rozumieją. To jest, że tak powiem, chamskie, ale przydatne, do takich tajnych rozmów.

Wielu wilamowian - szczególnie młodych, na swoich profilach na Facebooku używa także nie polskich, a wilamowskich imion i nazwisk. To wygląda bardzo oryginalnie i jednocześnie staje się sposobem publicznego deklarowania lokalnej tożsamości. Jednak większość wilamowian nie potrafi mówić po wilamowsku. Jeden z młodych chłopaków żalił się w taki sposób:

Na grupie zespołu regionalnego, co wrzuca [Tymek - przyp. aut.] wszystko jest po wilamowsku. No i ci, co nie rozumieją, to zaraz tam piszą i on pisze sprostowanie, polskie po prostu. Albo na przykład mamy spotkanie, próba jest o 18. I nagle jest zły, bo połowa ludzi nie przyszła. No bo nie wiedzieli. Ja czasami też jestem zły, bo widzę, że coś napisał i dzwonię do kolegi i pytam: e ty mi powiedz, co tam Tymek napisał, bo nie rozumie.

\footnotetext{
${ }^{6}$ Jypła to biała koszula z szerokimi rękawami, często haftowana, którą wilamowianki zakładają w stroju regionalnym pod oplecek (por. Król 2020a).
} 
Nawet ci, którzy uczą się tego języka, raczej nie używają go w sytuacjach codziennych. Obserwowałam to na przykład podczas jednej z letnich młodzieżowych imprez, zorganizowanej w przydomowym ogródku. Tymoteusz Król zwracał się do uczestników zabawy po wilamowsku i tylko wtedy niektórzy mu odpowiadali w tym języku. Miałam jednak poczucie, że ta sytuacja wydaje im się nienaturalna. Między sobą mówili wyłącznie po polsku. Natomiast absolutnie spontanicznie i dla własnej przyjemności podczas tej samej imprezy młodzież w pewnym momencie zaczęła tańczyć wilamowskie tańce odtwarzać układy sceniczne znane z zespołu. Umiejętność wilamowskiego tańca jest czymś, co ich łączy i pozwala dobrze się bawić także w sytuacji całkiem niescenicznej. Tańczyli dla siebie i własnej przyjemności, czego nie można powiedzieć o posługiwaniu się językiem wilamowskim.

Towarzyskie względy stały też za powodzeniem próby reanimacji lokalnego zwyczaju wielkanocnych śmiergustów. Ubrani w kolorowe stroje i maski chłopcy chodzą w noc między Wielkanocą a lanym poniedziałkiem po domach, oblewają tam dziewczyny wodą, a jednocześnie tańczą, bawią się itd. Współcześnie jest to zabawa w kręgu wtajemniczonych znajomych.

Grupa jest taka, że po prostu zespołowa, że ci, co z zespołu są, to chodzą... Jak się wejdzie do tego domu ... no to wtedy Tymek ma taki przykaz, że on cały czas prawie gra na tym akordeonie... A my tam chwilę posiedzimy, chwilę się pośmiejemy, a głównie to się bierze dziewczyny i się tańczy, albo panią domu, jak jest to też.... No to idziemy tam po kolei, kogo znamy, przez Wilamowice. Często jest tak, że kończymy około 5, 6 nad ranem, znajdujemy sobie jakąś miejscówę, żeby położyć się spać do tej 8. Wstajemy, idziemy do kościoła na 9 , no i jakoś trzeba przeżyć do południa i iść spać. Najgorsze jest to, że jak to się stało takie popularne, i telewizja zaczęła przyjeżdżać, i oni trochę zaczynają zawadzać, że tak powiem.

W lany poniedziałek bardzo wielu przebranych chłopaków wychodzi na rynek, żeby oblewać dziewczyny wodą lub nawet wrzucać je do przyciągniętej przez siebie wanny. Ten zwyczaj cieszy się wielką popularnością wśród wielu chłopaków z Wilamowic, interesuje także dziennikarzy, którzy co roku oblegają centrum miasteczka, żeby mieć jak najlepsze zdjęcia $z$ tego wesołego wydarzenia. Nieraz zdarzyło się, że w ferworze walki reporterzy byli potrącani, młodzież wpadała na kamery, wywiązywały się nieporozumienia - dlatego mój rozmówca mówił, że prasa „zawadza” - co świadczyłoby o tym, że zabawa nie jest na pokaz.

Czytelnicy z pewnością zauważyli, że w wielu opowieściach moich rozmówców pojawia się Tymoteusz Król jako uczestnik i inicjator pewnych działań. To ważne wydaje mi się, że jednym z kluczy do sukcesu liderów wilamowskości jest nie tylko organizowanie, ale też uczestniczenie, dawanie przykładu. Mogłabym przytoczyć podobne historie dotyczące wskrzeszenia działalności grup kolędniczych, nagrywania rekonstrukcji dawnych obrzędów czy organizowania na potrzeby publikacji sesji 
zdjęciowej, w której modelami zostali mieszkańcy Wilamowic w każdym wieku. Dużym przedsięwzięciem, o którym głośno było w okolicy, a które stało się całkiem wyjątkowym działaniem promującym wilamowskie dziedzictwo był prawdziwy ślub Justyny Majerskiej i Rafała Sznajdera. Para zaangażowała wielu mieszkańców w przygotowania i próbę przypomnienia niektórych tradycyjnych elementów dawnych wilamowskich wesel. W ogromnym skrócie wyglądało to następująco: para młoda i główni bohaterowie ubrani byli w stroje wilamowskie. Orszak z kapelą z domu młodego udał się do domu młodej, gdzie wykonywano odpowiednie wilamowskie piosenki. Potem z kościoła wszyscy szli pieszo do sali weselnej przy akompaniamencie wilamowskich marszy. Odbyły się też tradycyjne oczepiny, ze zdejmowaniem czepców i przekazaniem młodej mężowi.

Wiele dziewczyn mówiło mi podczas tej uroczystości, że zazdroszczą Justynie, że też by tak chciały. Takie wypowiedzi są znaczące, bo pokazują, że wilamowskość nawet przez młodzież może być traktowana jako coś atrakcyjnego. Krzysztof Kowalski pisal, że dla rozumienia dziedzictwa przeszłość nie jest wcale kluczowa. Najważniejsze stają się potrzeby teraźniejsze, współcześni ludzie, depozytariusze dziedzictwa (Kowalski 2013). Liderzy wilamowskości doskonale to wiedzą. Kolejnym ich doskonałym (z punktu widzenia popularyzacji dziedzictwa) pomysłem było zorganizowanie młodzieżowego teatru, który wystawia przedstawienia w języku wilamowskim. Na początku pomysłodawcy na warsztat wzięli popularne wśród młodzieży tematy - pokazali „Małego Księcia”, następnie „Hobbita”. Tekstom aktorów - wyłącznie po wilamowsku ${ }^{7}$, towarzyszyły też piosenki będące coverami znanych przebojów, również wykonane w lokalnym języku. Szczególnie „Hobbit” budził entuzjazm młodych wilamowian. Mogli pokazać na scenie coś, co jest im bliskie, co znają i lubią, jednocześnie wykorzystując umiejętności zdobyte na lekcjach języka wilamowskiego. Następnie postanowiono wystawić napisany w 1921 roku dramat lokalnego poety - Floriana Biesika, „Uf jer wełt” (Na tamtym świecie”). Dramat wzorowany na „Boskiej komedii” Dantego opowiada historię poety, zabiera też widzów w zaświaty, ukazując historię wilamowskiego języka. Reżyserzy, Justyna i Tymek, dopisali ostatnią scenę, w której język, dzięki działaniom rewitalizacyjnym, znów „żyje”.

Końcówka jest dodana, ta co podchodzi już pod rewitalizację tego, bo to jednak trzeba było trochę propagandy w to walnąć, żeby było wiadomo, że jednak trzeba kulturę krzewić i w ogóle. I co się dzieje z ludźmi, którzy są przeciwni krzewieniu kultury. Będzie morał taki jakby. Nie wszyscy aktorzy byli zachwyceni:W sumie to większość tak negatywnie podeszła do tego przedstawienia „Uf jer wełt”, w sensie, że większość nie za bardzo chce dramatów grać. Więc liczymy na to, żeby to szybko zagrać, nie żeby nikomu się to nie spodobało, tylko żeby nie było chętnych na więcej.

\footnotetext{
7 Spektakle mają napisy w języku polskim.
} 
Świadomość kulturowej wagi tekstu Biesika została jednak podkreślona.

No powiem „Piekło” Dantego było ciekawsze. No, ale to jest nasze. No, ale ogólnie to wszyscy czekamy, żeby to skończyć i duża część chce teraz jakąś komedię. Już nawet mieliśmy pomysł, z częścią ekipy chcieliśmy „Zemstę” machnąć. To by było fajne.

Nie „machnęli” jednak Fredry. Kolejny spektakl przygotowany przez grupę to właśnie „Odziewaczka” - „Ymertihła”, od opisu której rozpoczęłam niniejszy tekst. To przedstawienie skupia się już niemal wyłącznie na najtrudniejszych i najbardziej dramatycznych momentach w historii Wilamowic - wojnie i powojennych prześladowaniach. Ukazuje wilamowian w centrum międzykulturowego piekła, w którym zarówno Polacy, jak i Niemcy stają się prześladowcami. Justyna Majerska-Sznajder w wywiadzie dla TVP3 mówiła, że „scenariusz powstał na zasadzie wspomnień rodzinnych, które młodzież zbierała przez jakiś czas i tak jakby złączyła w jedną wspólną całość" (TVP3 2018). Przedstawienie powstawało już po zakończeniu przeze mnie badań, nie mogłam zatem porozmawiać $z$ wilamowianami o procesie jego tworzenia. $Z$ moich wcześniejszych rozmów wynika jednak, że kwestie krzywdy i nierozliczonych rachunków jako ważny składnik budowania lokalnego dziedzictwa pojawiały się przede wszystkim w ustach liderów wilamowskości. Poza nimi podobne treści usłyszałam tylko raz od ponad 90-letniej pani, której życie naznaczone było osobistymi dramatami dotyczącymi nie tylko powojennych prześladowań. Tymoteusz Król w wywiadzie mówił: „To jest nasza wizja świata i nasz język. I my chcemy mówić w tym języku i nadal naszą wizję świata kultywować” (TVP3 2018). Te słowa wydają mi się kluczowe dla zrozumienia całego procesu intensywnej pracy dziedzictwa. Jego liderzy są świadomi własnej pracy, a także faktu, że kultywują konkretną wizję świata. Są świadomi, że dziedzictwo to określona lektura przeszłości (Kowalski 2013), proces, który wciąż potrzebuje reinterpretacji, aktualizacji, zaś „wszelkie interwencje w dziedzictwo [...] zmieniają ich [ludzi - przyp. aut.] stosunek do tego, co robią. [...]. Modyfikują sposób, w jaki ludzie rozumieją swoją kulturę i postrzegają siebie samych" (Kirshenblatt-Gimblett 2011: 127). Czas pokaże, czy ta właśnie wizja wilamowskiego dziedzictwa traumy stanie się tą oficjalną, zinternalizowaną i dyskursywnie usankcjonowaną (por. Smith 2006). Ciekawe też, na ile uda jej się wspólistnieć z dziedzictwem postrzeganym jako lokalna oryginalność, powód do dumy i wspólnotowość, bo takie moim zdaniem postrzeganie dziedzictwa w Wilamowicach wciąż dominuje i za to również w dużej mierze odpowiedzialni są liderzy. Ciekawe w końcu, jak długo zainteresowanie rewitalizacją dziedzictwa będzie trwało, czy za parę lat znajdą się nowi, młodsi liderzy, którzy będą w stanie jeszcze bardziej zaktualizować treści przeszłości i uczynić je atrakcyjnymi dla nowych pokoleń wilamowian. 


\section{Bibliografia}

Barciak A. 2001. Pochodzenie mieszkańców [W]: A. Barciak (red.), Wilamowice: przyroda, historia, język, kultura oraz spoteczeństwo miasta i gminy. Wilamowice: Urząd Gminy, 98-115.

Galusek Ł., Jagodzińska K. 2014. Hasło: dziedzictwo [W:] M. Saryusz-Wolska, R. Traba (red.), Modi memorandi. Leksykon kultury pamięci. Warszawa: Wydawnictwo Naukowe Scholar, 496-500.

Furtak E. 2020. Kraina wyklętego języka powinna być strefa wolnq od nienawiści. Gazeta Wyborcza Bielsko Biała - wydanie internetowe: https://bielskobiala.wyborcza.pl/bielskobiala/7,88025,25768477,kraina-wykletego-jezyka-powinna-być-strefa-wolna-od-nienawisci. html, 02.01.2021.

Gillman D. 2010. The Idea of Cultural Heritage. Revised Edition, Cambridge-New York: University Press.

Geertz C. 2000. Myśl potoczna, jako system kulturowy [W:] Interpretacje kultur, wybrane eseje, Kraków: WUJ, 81-100.

Kirshenblatt-Gimblett B. 2011. Od etnologii do dziedzictwa. Rola muzeum, przeł. K. I J. Sieliccy, Etnografia Nowa 3, 125-136.

Kowalski K. 2013. O istocie dziedzictwa europejskiego - rozważania, Kraków: Międzynarodowe Centrum Kultury.

Król T. 2016. Czym jest dla dzisiejszych Wilamowian jezzyk wilamowski? Różne funkcje, różne postawy jezzykowe, „Łódzkie Studia Etnograficzne” 55, 241-264.

Król T. 2020a. Strój kobiecy w latach 1945-2000 [W:] B. Chromik et al. (red.) Wilamowianie i ich stroje, Warszawa: Wydział „Artes Liberales” UW, 143-214.

Król T. 2020b. Strój kobiecy we wspótczesności 2000 [W:] B. Chromik et al. (red.) Wilamowianie i ich stroje, Warszawa: Wydział „Artes Liberales” UW, 215-238.

Libera Z., Robotycki C. 2001. Wilamowice i okolice w ludowej wyobrazni [W:] A. Barciak. (red.) Wilamowice. Przyroda, historia, jezyk, kultura oraz spoteczeństwo miasta i gminy. Wilamowice: Urząd Gminy w Wilamowicach, 371-400.

Lowenthal D. 1998. The Heritage Crusade and the Spoils of History, Cambridge: Cambridge University Press.

Małanicz-Przybylska M. 2018. Dziedzictwo jako proces $i$ dziatanie - wytwarzanie dziedzictwa w Wilamowicach, Dziedzictwo Kulturowe Wsi t. 2, 75-90.

Małanicz-Przybylska M. 2019. Bez muzyki, bez śpiewu nie ma świata. Muzyka w Wilamowicach. Warszawa: Wydział „Artes Liberales” UW.

Michalczyk M. 2001. Zajęcia ludności, [W:] A. Barciak (red.) Wilamowice. Przyroda, historia, język, kultura oraz społeczeństwo miasta i gminy. Wilamowice: Urząd Gminy w Wilamowicach, 271-278.

Reyniak, J. Z. 2001. Osadnictwo pradziejowe i wczesnośredniowieczne. Stanowiska osadnicze do XVIII w. [W:] A. Barciak (red.), Wilamowice. Przyroda, historia, jezzy, kultura oraz spoteczeństwo miasta i gminy. Wilamowice: Urząd Gminy w Wilamowicach, 71-81. 
Shils E. 1984. Tradycja, przeł. J. Szacki [W:] J. Kurczewska, J. Szacki (red.), Tradycja i nowwoczesnośc, Warszawa: Czytelnik, 30-89.

Sepioło M. 2018, Mate Wilamowice od ponad 700 lat maja wtasny jezyk. Wiele wskazuje, że zostanie ocalony od zapomnienia. Gazeta Wyborcza - wydanie internetowe, https://weekend.gazeta.pl/ weekend/1,177334,24300944,male-wilamowice-od-ponad-700-lat-maja-wlasny-jezyk -wiele-wskazuje.html, 03.01.2021.

Smith L. 2006. Uses of Heritage, Londyn-Nowy Jork: Taylor \& Francis Ltd.

Smith L. 2016. „Zwierciadto dziedzictwa”: narcystyczna iluzja czy zwielokrotnione odbicie?, Rocznik Antropologii Historii VI (9), 25-44.

Wicherkiewicz T. 2003. The Making of Language; The case of idiom of Wilamowice, Berlin-New York: Mouton de Gruyter.

TVP3 Katowice 2018. „Ymertibta” na zakończenie Dni Języka Ojczystego. https://katowice.tvp. p1/36163336/ymertihla-na-zakonczenie-dni-jezyka-ojczystego, 03.01.2021.

Autorka:

Dr Maria Małanicz-Przybylska

Instytut Etnologii i Antropologii Kulturowej

Uniwersytet Warszawski

Żurawia 4, 00-503 Warszawa

e-mail: maria.malanicz-przybylska@uw.edu.pl 